\title{
Anti-microbial Activity and Anti-inflammatory Effects of Fucoidan Extracts
}

\author{
Ah Reum Lee ${ }^{1}$, Seong-Soo Roh ${ }^{1}$, Hyun-Kyoung Kim ${ }^{2 *}$ \\ ${ }^{1}$ College of Korean Medicine, Daegu Haany University, Daegu, Korea \\ ${ }^{2}$ Department of Food Science and Engineering, Seowon University, Cheongju-si, Chungcheongbuk-do, Korea
}

\author{
*Corresponding author: Hyun-Kyoung Kim, \\ Department of Food Science and Engineering, \\ Seowon University, 377-3 Musimseo-ro, \\ Seowon-gu, Cheongju-si, Chungcheongbuk-do \\ 28674, Korea \\ Tel.: +82 432998474 \\ Fax: +82 432998470 \\ Email: kimhk4@seowon.ac.kr
}

\section{Received August 5, 2017}

Revised December 20, 2017

Accepted January 11, 2018

Published June 30, 2018

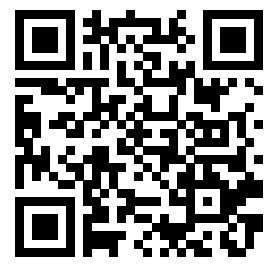

\begin{abstract}
Purpose: This study aimed to evaluate fucoidan extract as a cosmetic material. Methods: To assess anti-microbial efficacy, Staphylococcus aureus (S. aureus) was treated with fucoidan extract and zones of inhibition were measured. In addition, the anti-inflammatory effect was confirmed in RAW 264.7 cells, and fucoidan extract was applied to the dorsal skin of Sprague-Dawley (SD) rats to evaluate single dose toxicity. Results: Fucoidan extract did not exhibit cytotoxicity at concentrations up to $1,000 \mu \mathrm{g} / \mathrm{mL}$ in skin fibroblasts. Furthermore, when $S$. aureus was treated with $1 \%$ fucoidan extract, clear zones of $1.52 \pm 0.34 \mathrm{~cm}$ formed, confirming sufficient anti-microbial activity. When RAW 264.7 cells were treated with fucoidan extract, nitric oxide (NO) production decreased in a concentration-dependent manner and the production of inflammation-related cytokines, such as interleukin 1 beta (IL1ß), tumor necrosis factor alpha (TNF $\alpha)$, and prostaglandin $\mathrm{E}_{2}\left(\mathrm{PGE}_{2}\right)$, decreased. When fucoidan was applied at various concentrations to rats, symptoms did not change for more than 14 days, and there was no change in body or organ weights. Conclusion: Fucoidan extract is not cytotoxic and has anti-microbial and anti-inflammatory effects. Therefore, it is suitable for use as a cosmetic material.
\end{abstract}

Keywords: Fucoidan, Cell toxicity, Anti-microbial efficacy, Anti-inflammatory effect, Dermal toxicity

\section{Introduction}

피부는 인체에서 가장 큰 장기로 외부의 환경으로부터 인체 를 보호하여 체내 항상성을 유지하는 기능을 한다(Gkogkolou \& Böhm, 2012). 피부는 대사과정을 통하여 다양한 유리기가 생성 되는데, 이는 노화, 홍반, 부종, 피부암과 같은 다양한 염증반응 의 원인이 된다(Lee et al., 2016b). 염증 반응은 피부 내 대식세 포가 lipopolysaccharide (LPS) 또는 interferon gamma (IFNY)와 같은 자극에 의해 $\mathrm{NO}$, prostaglandins $(\mathrm{PGs})$ 를 증가시켜(Nathan, 1987), IL1ß, TNF $\alpha$ 와 같은 염증성 사이토카인을 발현시켜 일어 난다(Rostasy et al., 2000). 또한 피부 내에서 염증성 사이토카 인이 발현되면 피부 각질형성세포의 증식 속도를 급격히 감소시 키고 진피층의 기질형성을 억제함으로써 피부가 손상되었을 때 치유 속도를 저하시키며 아토피성 피부염, 건선과 같은 피부질환 을 유발한다고 보고되어 있다(Kang et al., 2017).
피부질환을 유발시키는 것으로 보고된 미생물은 여드름 균인 Propionibacterium acnes (P. acnes)과 비듬과 모낭염의 원 인균인 Malassezia furfur (M. furfur)가 대표적이며(Park \& Choi, 2011), 황색포도상구균 $S$. aureus은 피부 배양 검사 시 흔히 검출되는 균으로써, 아토피 피부염과 밀접한 연관이 있는 것으로 알려졌다(Zollner et al., 2000). S. aureus 균은 피부 에 상재하면서 독소를 분비하는데 이 독소가 초항원으로 작용하 여 피부 내 T림프구의 면역반응을 유도하며, T helper 2 (Th2) 세포에 의한 면역반응을 유발하여 아토피 피부염을 악화시킨다 (Kim et al., 2006).

후코이단(fucoidan)은 스웨덴 웁살라(Uppsala) 대학의 D. Klein 교수가 처음 발견한 것으로 다시마에서 분비되는 물질 중 황산기가 함유된 다당류 성분을 말한다(Choi et al., 2000). 현 재는 미역귀, 미역 등에서도 후코이단이 추출되고 있으며, 혈액 응고를 방지하는 물질로 알려진 헤파린(heparin)과 매우 유사한 
구조를 이루고 있다(Pereira et al., 1999). 최근에는 피부 보습 (Cha et al., 2010), 피부 미백(Song et al., 2015), 아토피 피 부염 및 알레르기 증상 완화 효과(Oomizu et al., 2006) 등 피 부와 관련된 연구들이 다양하게 진행되고 있다. 이처럼 후코이단 추출물에 대한 연구가 활발하게 진행되고 있음에도 불구하고 미 역귀에서 추출한 후코이단 추출물의 항균, 항염증에 대한 연구는 미미한 실정이다.

따라서 본 연구에서는 미역귀에서 후코이단을 추출하여 세포 독성, 항염, 항균, 경피 투여 독성 효능을 실험하여 화장품 소재 로서의 유효성을 확인하고자 하였고 유의한 결과를 얻어 보고하 는 바이다.

\section{Methods}

\section{1. 시료 추출}

후코이단을 추출하기 위하여 미역귀를 건조기 $(\mathrm{HK}-\mathrm{D} 0135 \mathrm{~F}$; HANKUK S\&I, Korea)로 건조하였고 분쇄기(RT-08; Rong Tsong Precision Technoloy Co., Taiwan)를 이용하여 분쇄한 후, 미역귀 $25 \mathrm{~g}$ 에 $100 \mathrm{~mL}$ 의 acetone (Sigma-Aldrich, USA) 을 가하여 실온에서 $12 \mathrm{~h}$ 동안 방치하였다. 그 다음, $4^{\circ} \mathrm{C}$ 조건 에서 $8,000 \times \mathrm{g}$ 로 $10 \mathrm{~min}$ 동안 원심분리기(1730R; LaboGene, Denmark)로 분리 후 상층액을 분리하였다. 잔사에 다시 100 $\mathrm{mL}$ 의 acetone (Sigma-Aldrich)을 가하여 $12 \mathrm{~h}$ 동안 방치하 였다. $12 \mathrm{~h}$ 후에, 같은 조건 $\left(4^{\circ} \mathrm{C}, 10 \mathrm{~min}, 8,000 \times \mathrm{g}\right)$ 에서 원 심 분리하여 상층액을 분리하였다. 잔사에 증류수 $500 \mathrm{~mL}$ 을 가 하여 $40^{\circ} \mathrm{C}$ 에서 $24 \mathrm{~h}$ 동안 추출하고 Buchner 여과장치(Korea material scientific, Korea)를 이용하여 여과지(Whatman ${ }^{\circledR}$ Filter Papers No. 2; GE healthcare Life Sciences, UK) 로 여과 한 후 여과액을 rotary vacuum evaporator (JP/ $\mathrm{N}-1000 \mathrm{X}$; Sunileyela, Korea)를 사용하여 $50^{\circ} \mathrm{C}$ 에서 감압 농 축하였다. 잔사에 증류수 $500 \mathrm{~mL}$ 과 zinc sulfate (SigmaAldrich) $25 \mathrm{~mL}, 0.3 \mathrm{~N}$ barium hydroxide (Sigma-Aldrich) $25 \mathrm{~mL}$ 을 가하여 $60^{\circ} \mathrm{C}$ 에서 $2 \mathrm{~h}$ 동안 추출하였다. $4^{\circ} \mathrm{C}$ 조건에서 $5,000 \times \mathrm{g}$ 로 $10 \mathrm{~min}$ 동안 원심 분리하여 얻은 상층액을 rotary vacuum evaporator (JP/N-1000X; Sunileyela, Korea)로 감압 농축하여 동결 건조기(Labconco FreeZone 7740020; Labconco, USA)를 이용하여 동결 건조한 후 얻은 후코이단 파 우더를 냉장 보관하여 실험에 사용하였다.

\section{2. 세포 독성 측정}

실험에 사용된 skin fibroblast 세포는 한국세포주은행 (Korean Cell Line Bank, KCLB, Korea)에서 구입하여 $10 \%$ fetal bovine serum (FBS; Gibco ${ }^{\mathrm{TM}}$, Thermo Fisher
Scientific, USA)이 포함된 Dulbeccos's Modified Eagle's Medium (DMEM; $\mathrm{Gibco}^{\mathrm{TM}}$ ) 배지에서 배양하였다. 배양한 세 포를 96 well microplates에 분주하여 $5 \% \mathrm{CO}_{2} 37^{\circ} \mathrm{C}$ 배양기에 서 $24 \mathrm{~h}$ 배양한 후, $10-1000 \mu \mathrm{g} / \mathrm{mL}$ 농도의 후코이단 추출물 을 포함한 새로운 배지를 넣어주었다. $24 \mathrm{~h}$ 배양 후, 각 well의 상층액 $0.7 \mathrm{~mL}$ 를 제거하고 3-[4,5-dimethylthiazol-2-y]2,5-diphenyl terazolium bromide (MTT; Sigma-Aldrich) 용액을 $5 \mathrm{mg} / \mathrm{mL}$ 이 되게 분주하여 $4 \mathrm{~h}$ 동안 배양하였다. 배 양 종료 후 각 well 마다 $1 \mathrm{~mL}$ 의 isoprothiolane (SigmaAldrich)을 넣어 보라색 결정체가 완전히 용해될 때까지 혼합 하였다. 그 후 $570 \mathrm{~nm}$ 파장에서 UV-Vis spectrophotometer (UV1800; Shimadzu, Japan)를 사용하여 측정하였다(Lee et al., 2016a).

\section{3. 항균 효능 측정}

후코이단의 항균 효과를 평가하기 위하여 생물자원센터 (Korean Collection for Type Cultures, KCTC, Korea)에서 분양 받은 S. aureus (KCTC 1621)를 계대 배양하여 사용하였 으며 항균력 측정은 paper disc 법을 사용하였다(Choi et al., 2012). 평판 배지에 배양된 각 균주를 1 백금이를 취해서 액 체 배지 $10 \mathrm{~mL}$ 에서 18-24 h 배양하여 활성화시켰다. 액체 배 지 $10 \mathrm{~mL}$ 에 균액을 $0.1 \mathrm{~mL}$ 씩 접종하여 3-6 h 배양한 후 평 판 배지 1 개당 균액을 약 $10^{7}$ cells 되게 접종하여 멸균 면봉 으로 균일하게 도말하였다. 멸균된 filter paper disc $(8 \mathrm{~mm}$; Advantec, Japan)를 고체 평판배지에 올려놓은 다음 각각 45 $\mu \mathrm{L} / \mathrm{disc}$ 가 되도록 시료를 농도별로 흡수시켰고 $35^{\circ} \mathrm{C}$ 에서 $18-$ $24 \mathrm{~h}$ 배양하여 disc 주위의 clear zone 즉 균 성장억제 영역의 직경 $(\mathrm{mm})$ 을 측정하여 항균력을 평가하였다(Kim et al., 2010).

\section{4. 항염증 효능 측정}

\section{1) $\mathrm{NO}$ 농도 측정}

후코이단의 항염증 반응을 평가하기 위하여 RAW 264.7 세 포를 한국세포주은행에서 구입하여 Roswell Park Memorial Institute (RPMI) medium 1640 (Gibco ${ }^{\mathrm{TM}}$ ) 배지에 10\% fetal bovine serum (FBS)를 포함하여 배양하였다. 24 well plates 에 세포는 $2 \times 10^{5}$ cells $/ \mathrm{mL}$ 의 밀도로 현탁하였고, 50-400 $\mu \mathrm{g} /$ $\mathrm{mL}$ 농도로 후코이단 추출물을 처리하였다. 염증반응을 유발 하기 위하여 $1 \mu \mathrm{g} / \mathrm{mL}$ lipopolysaccharides (LPS; SigmaAldrich)로 자극한 후 $24 \mathrm{~h}$ 동안 배양하였고 세포 상층액을 취 해 96 well microplates에 분주하였다. 그 후 $100 \mu \mathrm{L}$ 의 그리 스 시약 (Griess reagent; 0.5\% sulphanilamide (SigmaAldrich), 2.5\% phosphoric acid (Sigma-Aldrich) 및 0.5\% $\mathrm{N}-(1-$ naphthyl) ethylenediamine dihydrochloride (NEDHC; Sigma-Aldrich)을 첨가하였으며 UV-Vis spectrophotometer 
를 이용하여 $540 \mathrm{~nm}$ 에서 흡광도를 측정하였고 $\mathrm{NO}$ 의 농도는 아 질산염의 표준 곡선으로부터 계산하였다(Kim et al., 2012).

\section{2) 염증 관련 cytokine 측정}

RAW 264.7 세포를 6 well microplates에 $3 \times 10^{5}$ cells $/ \mathrm{mL}$ 가 되도록 분주하고, $24 \mathrm{~h}$ 동안 배양한 후, LPS를 $500 \mu \mathrm{g} / \mathrm{mL}$ 농도로 처리하여 염증반응을 유발하였다. 세포에 후코이단 50 , $100,200,400 \mu \mathrm{g} / \mathrm{mL}$ 로 처리하고, $24 \mathrm{~h}$ 동안 배양한 후 세포 배양액을 수거하여 배양액에 함유된 IL $1 \beta, \mathrm{TNF} \alpha$ 는 Milliplex map cytokine kit (Millipore, USA)을 이용하여 측정하고, $\mathrm{PGE}_{2}$ 는 enzyme-linked immunosorbent assay (ELISA) kit (Calbiochem, USA)을 이용하여 측정하였다(Jung et al., 2014).

\section{5. 단회 경피 투여 독성 평가}

5 주령 $\mathrm{SD}$ 흰쥐 암 - 수컷 50 마리를 (주)코아텍 $(\mathrm{COATECH}$, Korea)으로부터 공급받아 1 주일간의 실험실 적응 과정을 거친 후 실험에 사용하였다. 동물 사육실 환경은 온도 $23 \pm 2{ }^{\circ} \mathrm{C}$, 상 대습도 $55 \pm 10 \%$, 환기횟수 12 회/h, 조명주기 $12 \mathrm{~h} \mathrm{(07:00-}$ 19:00), 조도 150-300 lux로 조절되었다. 사료는 고형 사료로 (주)다물사이언스(Korea)에서 공급하였고 멸균 정제수를 자유롭 게 섭취하도록 하였다. 적응 기간 종료 후 이상이 없는 실험 동 물을 선별하여 수컷과 암컷 흰 쥐를 각 군당 10 마리씩 평균체 중이 일정하게 되도록 무작위로 배치하였다. 실험군은 대조군 (vehicle), 후코이단 추출물 $1 \%$ 처치군 (fucoidan $1 \%$ ), 후코이단 추출물 $5 \%$ 처치군 (fucoidan $5 \%$ ), 후코이단 추출물 $10 \%$ 처치군 (fucoidan 10\%)으로 각 10마리씩 나누어서 사용하였다. 실험 동 물의 등 부위를 약 $5 \times 2.5 \mathrm{~cm}^{2}$ 를 미리 제모한 후 후코이단 추출 물을 $30 \%$ 에탄올에 적정 처치 용량으로 용해하여 제모한 부위에 $1 \mathrm{~mL}$ 를 고르게 도포하였다. 처치 후 14 일간 매일 관찰하여 일 반증상을 기록하였고, 처치 당일의 절식체중과 익일을 포함하여 3 일 간격으로 체중, 음수 및 사료 섭취량을 각각 측정하였다. 또 실험물질 투여 후 14 일이 되는 시점에 절식시킨 후 15 일째에 부 검하여 주요 장기의 중량을 측정하였고 절식체중에 대한 상대 장 기 중량으로 산출하여 비교하였으며, 부검 시 육안적 병리소견 및 이상 병변이 관찰된 장기 및 조직에 대해 조직병리학적으로 분석 하였다. 그 결과로부터 개략의 치사량( $10 \%$ 치사량)을 산출하였 다.

\section{6. 통계처리}

실험결과는 Statistical Package for the Social Sciences (SPSS) Version 22.0 (IBM, USA)의 unpaired Student's $t$-test를 이용하여 통계처리 하였으며, 그 값은 평균표푼편차 (mean \pm standard deviation)로 표기하였다. 유의성은 $p<0.05$ 수준에서 판단하였다.

\section{Results and Discussion}

\section{1. 세포 독성}

후코이단 추출물을 $10-1,000 \mu \mathrm{g} / \mathrm{mL}$ 농도로 skin fibroblast 세포에 처리한 군과 아무것도 처리하지 않은 대조군의 세포 생 존율을 비교하였을 때 생존율은 각각 $100.0 \pm 0.9 \%, 98.3$ $\pm 2.3 \%, 96.6 \pm 3.4 \%, 94.3 \pm 2.9 \%, 91.1 \pm 3.3 \%, 90.2 \pm$ $4.7 \%$ 그리고 $87.3 \pm 3.5 \%$ 로 모든 농도에서 유의적인 세포독 성을 나타내지 않았다(Figure 1).

\section{2. 항균력 평가}

S. aureus은 대표적인 피부 상재균으로서 단독으로 염증을 일 으키지는 않지만 피부 염증이 발생하였을 경우 2 차 감염을 일으 켜 염증을 악화시키고 여드름에도 영향을 미치는 것으로 알려져 있다(Han et al., 2009). 후코이단 추출물의 항균효과를 알아보 기 위해, S. aureus 균 배양 후 후코이단 추출물을 $0,0.01 \%$, $0.1 \%, 1 \%$ 농도로 처리하여 $48 \mathrm{~h}$ 후에 항균활성을 살펴보았다. 실험 결과, Figure 2에서 나타난 바와 같이 후코이단 추출물을 처리한 부분에서 생육 저해환이 형성되었으며, $0.01 \%, 0.1 \%$, $1 \%$ 의 농도로 처리하였을 때 각각 $1.32 \pm 0.54 \mathrm{~cm}, 1.44 \pm 0.68$ $\mathrm{cm}, 1.52 \pm 0.34 \mathrm{~cm}$ 의 생육 저해환이 형성되어 추출물의 농도 에 비례하여 효능이 증가하는 것을 확인할 수 있었다(Table 1).

\section{3. 항염증 효능 평가}

1) NO 생성량 측정

L-arginine은 L-citrulline과 $\mathrm{NO}$ 로 변하는데, 생성된 $\mathrm{NO}$ 는 빠른 반응을 통하여 안정된 nitrogen dioxide (이산화질소, $\mathrm{NO}_{2}$ ), nitrite (아질산염, $\mathrm{NO}_{2}^{-}$)으로 변한다(Kim et al., 2011). 그리스 시약은 아질산염과 화학 반응하여 보라색의 아조염을 형성하고

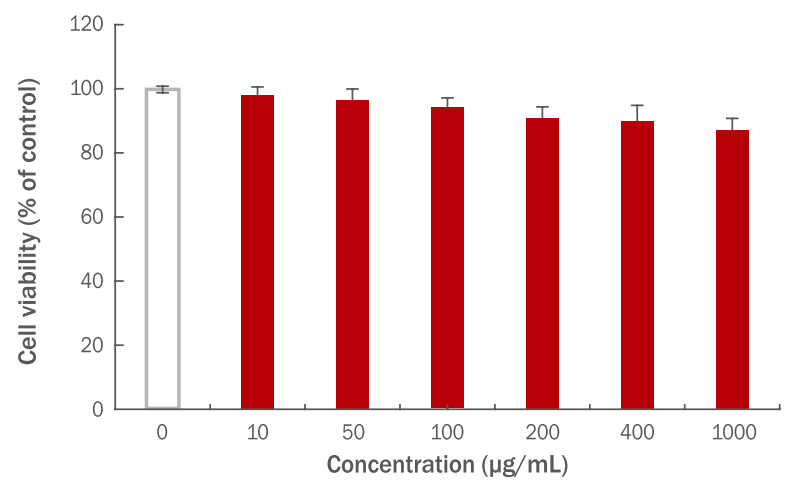

Figure 1. Effects of fucoidan extract on skin fibroblast cell viability.

Skin fibroblast cells were incubated with various concentrations of fucoidan extract for $24 \mathrm{~h}$. Fucoidan extract did not exhibit cytotoxicity at concentrations up to $1,000 \mu \mathrm{g} / \mathrm{mL}$. 


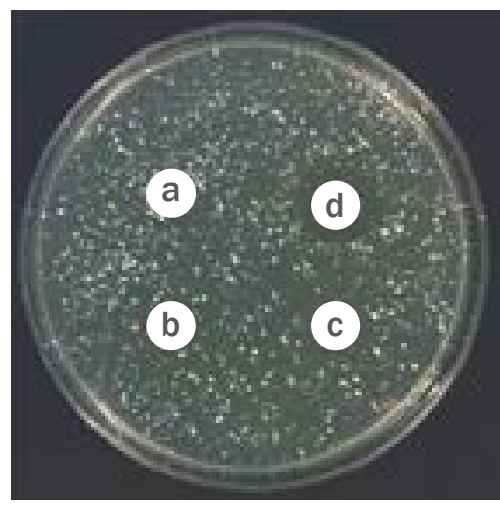

Figure 2. Anti-microbial activity of fucoidan extracts on S. aureus. Fucoidan extract at 0\% (a), 0.01\% (b), 0.1\% (c), and 1\% (d). S. aureus was treated with varying concentrations of fucoid extract, and the diameter of the zone of inhibition was measured. The zone of inhibition of $S$. aureus treated with $1 \%$ fucoidan extract was $1.52 \pm 0.34 \mathrm{~cm}$, confirming that fucoidan extracts have sufficient anti-microbial activity. S. aureus, Staphylococcus aureus.

이것은 $\mathrm{NO}$ 의 농도와 일치하기 때문에, 아조염의 농도로부터 아질 산염의 농도를 측정하여 NO 생성량을 측정할 수 있다(Bae \& Bae, 2012). 후코이단 추출물의 RAW 264.7 세포에 대한 항염증 효능 을 평가한 결과, $1 \mu \mathrm{g} / \mathrm{mL}$ 농도의 LPS로 염증반응을 유발시킨 배

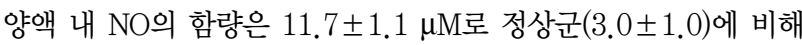
증가되었다. 그러나, 후코이단 추출물을 $50,100,200,400 \mu \mathrm{g} /$ $\mathrm{mL}$ 로 처리한 실험군의 배양액 내 $\mathrm{NO}$ 의 함량은 각각 $11.6 \pm 1.5$, $11.7 \pm 1.1,10.7 \pm 1.9,9.5 \pm 1.7 \mu \mathrm{M}$ 로 나타났고, 특히 후코이단 추출물 농도 $400 \mu \mathrm{g} / \mathrm{mL}$ 로 처리한 실험군은 LPS를 단독 처리한 대조군에 비해 유의하게 감소함을 확인할 수 있었다(Figure 3).

\section{2) 염증성 cytokine 측정}

외부 자극에 의하여 피부는 홍반, 염증, 동통 등의 반응이

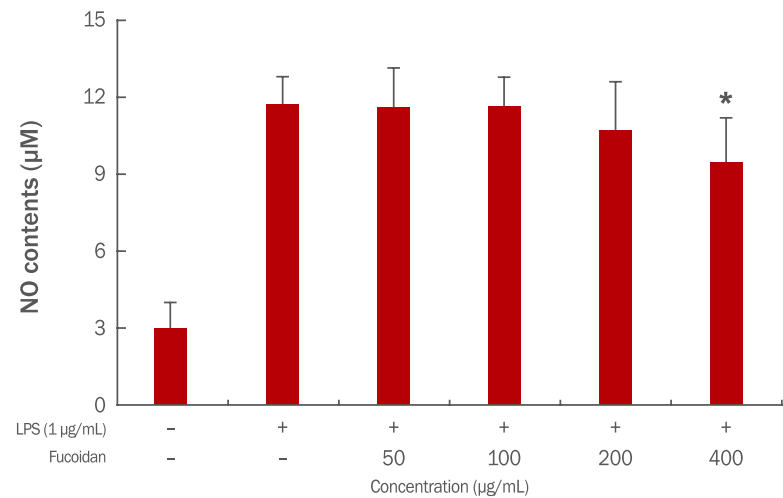

Figure 3. Effects of fucoidan extracts on LPS-induced NO production in RAW 264.7 cells.

RAW 264.7 cells were treated with $50-400 \mu \mathrm{g} / \mathrm{mL}$ of fucoidan extracts and LPS $(1 \mu \mathrm{g} / \mathrm{mL})$ for $24 \mathrm{~h}$. NO production decreased in a concentration-dependent manner. Significance: ${ }^{*} p<0.05$ compared with LPS treated RAW 264.7 cells without fucoidan. NO, nitric oxide; LPS, lipopolysaccharide.

일어나고 이는 proinflammatory cytokine인 TNF $\alpha$, IL1 $\beta$, monocyte chemoattractant protein1 (MCP1) 등에 의해 매개된 다(Kim et al., 2004). 후코이단 추출물이 RAW 264.7 세포에 대한 항염증 효능을 평가한 결과, $1 \mu \mathrm{g} / \mathrm{mL}$ 농도의 LPS로 염증반응을 유 발시킨 배양액 내 IL1ß의 함량은 $173.3 \pm 23.9 \mathrm{pg} / \mathrm{mL}$ 로 정상군에 비해 유의하게 증가되었다. 그리고 후코이단 추출물을 $400 \mu \mathrm{g} /$ $\mathrm{mL}$ 로 처리한 실험군의 배양액 내 IL1ß의 함량은 $136.8 \pm 13.2$ $\mathrm{pg} / \mathrm{mL}$ 으로 나타나 LPS를 단독 처리한 대조군에 비해 감소되었 으나, 유의성은 보이지 않았다(Figure 4A). LPS로 염증반응을 유발시킨 배양액 내 $\mathrm{TNF} \alpha$ 의 함량은 $469.4 \pm 49.4 \mathrm{pg} / \mathrm{mL}$ 로 정 상군에 비해 증가되었고, 후코이단 추출물을 $200,400 \mu \mathrm{g} / \mathrm{mL}$ 로 처리한 실험군은 LPS를 단독 처리한 대조군에 비해 유의한 감소 가 나타났다(Figure $4 \mathrm{~B}$ ).

Table1. Anti-microbial activity of fucoidan extracts on $\mathbf{S}$. aureus

\begin{tabular}{lcc}
\hline Materials & Concentration (\%) & Inhibition zone diameter $(\mathrm{cm})$ \\
& 1 & $1.52 \pm 0.34$ \\
Fucoidan extracts & 0.1 & $1.44 \pm 0.68$ \\
& 0.01 & $1.32 \pm 0.54$ \\
\hline
\end{tabular}

S. aureus, Staphylococcus aureus.

Table 2. Evaluation of body weight and food and water intake in SD-rats

\begin{tabular}{|c|c|c|c|c|c|c|c|c|c|c|c|c|c|c|c|c|}
\hline Day & & 0 & 1 & 2 & 3 & 4 & 5 & 6 & 7 & 8 & 9 & 10 & 11 & 12 & 13 & 14 \\
\hline \multirow{2}{*}{$\begin{array}{l}\text { Body weight } \\
\text { (g) }\end{array}$} & $M$ & 153 & 165 & 172 & 184 & 192 & 199 & 207 & 214 & 222 & 231 & 238 & 243 & 253 & 260 & 268 \\
\hline & $\mathrm{F}$ & 138 & 142 & 150 & 157 & 163 & 170 & 180 & 186 & 195 & 203 & 210 & 219 & 228 & 236 & 242 \\
\hline \multirow{2}{*}{$\begin{array}{l}\text { Food intake } \\
(\mathrm{g} / \mathrm{g})\end{array}$} & $M$ & 0.17 & 0.16 & 0.17 & 0.15 & 0.18 & 0.16 & 0.16 & 0.18 & 0.17 & 0.16 & 0.15 & 0.16 & 0.17 & 0.17 & 0.16 \\
\hline & $\mathrm{F}$ & 0.15 & 0.14 & 0.16 & 0.16 & 0.18 & 0.17 & 0.16 & 0.16 & 0.16 & 0.18 & 0.17 & 0.16 & 0.14 & 0.16 & 0.16 \\
\hline \multirow{2}{*}{$\begin{array}{l}\text { Water intake } \\
(\mathrm{mL} / \mathrm{g})\end{array}$} & $M$ & 0.22 & 0.24 & 0.26 & 0.25 & 0.25 & 0.24 & 0.23 & 0.23 & 0.24 & 0.25 & 0.23 & 0.24 & 0.24 & 0.25 & 0.24 \\
\hline & $\mathrm{F}$ & 0.24 & 0.25 & 0.24 & 0.23 & 0.24 & 0.22 & 0.24 & 0.26 & 0.25 & 0.26 & 0.25 & 0.25 & 0.24 & 0.23 & 0.23 \\
\hline
\end{tabular}

M, male; F, female; SD, Sprague-Dawley. 

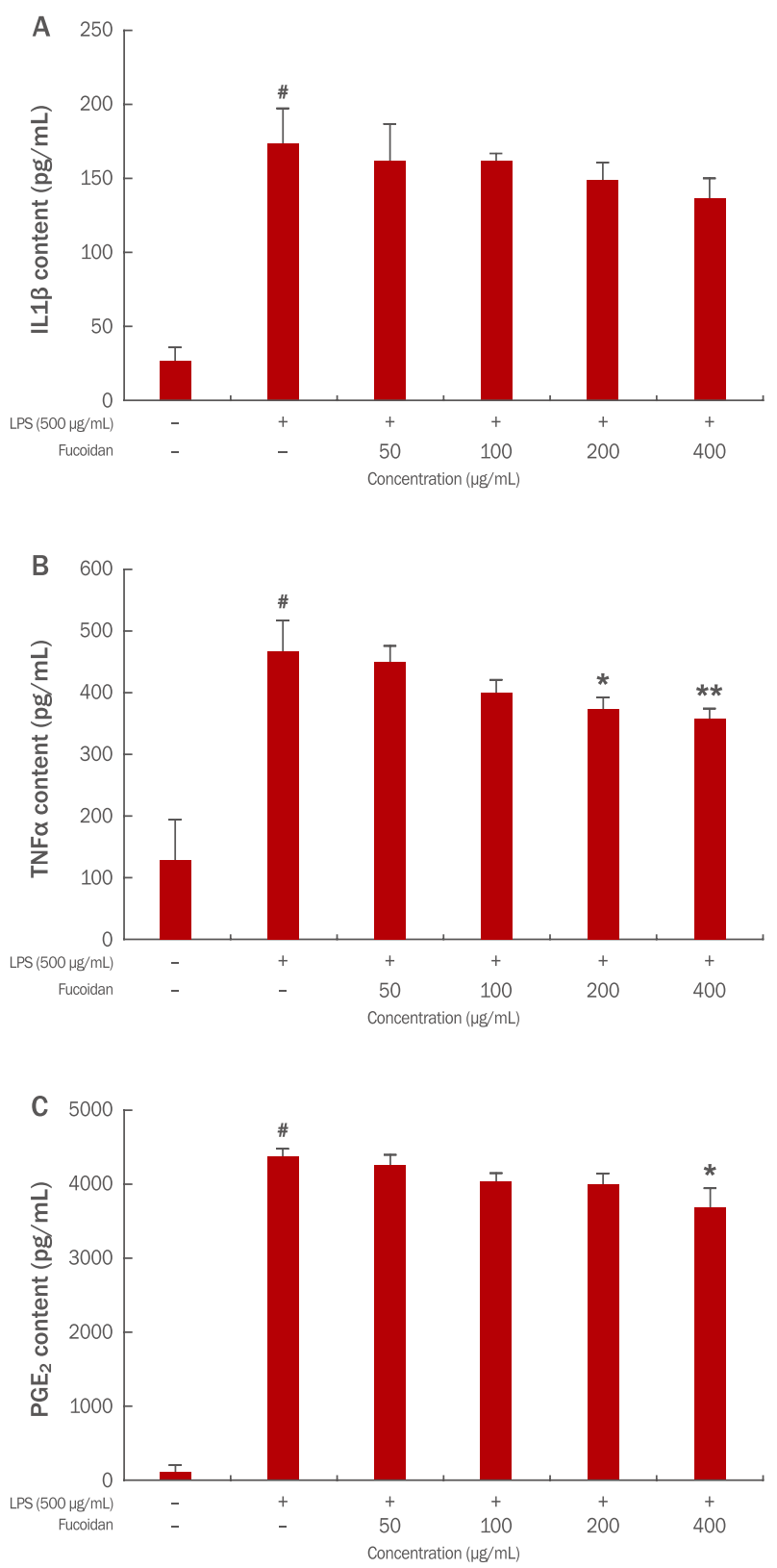

Figure 4. Effects of fucoidan extracts on LPS-induced inflammatory cytokine production in RAW 264.7 cells.

RAW 264.7 cells were treated with $50-400 \mathrm{mg} / \mathrm{mL}$ of fucoidan extracts and LPS (500 $\mu \mathrm{g} / \mathrm{mL})$ for $24 \mathrm{~h}$, and IL1 $\beta$ (A), TNF $\alpha(B)$, and $\mathrm{PGE}_{2}(\mathrm{C})$ were determined. Inflammation-related cytokines, such as IL1 $\beta$, TNF $\alpha$ and $P E_{2}$ were decreased. Significance: ${ }^{*} p<0.05,{ }^{* *} p<0.01$ compared with LPS treated RAW 264.7 cells in the absence of fucoidan; ${ }^{*} p<0.05$ compared with LPS non-treated RAW 264.7 cells in the absence of fucoidan. IL1 $\beta$, interleukin 1 beta; TNF $\alpha$, tumor necrosis factor alpha; $\mathrm{PGE}_{2}$, prostaglandin $\mathrm{E}_{2}$; LPS, lipopolysaccharide.

$\mathrm{PGE}_{2}$ 는 비만세포나 대식세포에 의하여 분비되며 염증 부위의 부종, 통증, 감각 과민을 일으키는 histamine, $\mathrm{NO}$ 등과 함께 혈 관 투과성을 증가시켜 백혈구의 염증부위로의 주화성을 증가시
킨다(Lee et al., 2012). $\mathrm{PGE}_{2}$ 의 함량은 대조군(4363.8 \pm 102.3 $\mathrm{pg} / \mathrm{mL}$ )에 비해 후코이단 추출물을 $50,100,200,400 \mu \mathrm{g} / \mathrm{mL}$ 로 하였을 때, 각각 $4243.6 \pm 136.7 \mathrm{pg} / \mathrm{mL}, 4018.6 \pm 119.8$ $\mathrm{pg} / \mathrm{mL}, 3993.4 \pm 140.6 \mathrm{pg} / \mathrm{mL}, 3677.6 \pm 257.8 \mathrm{pg} / \mathrm{mL}$ 으로 $\mathrm{LPS}$ 를 단독 처리한 대조군에 비해 농도의존적으로 감소되었으 며, 특히 후코이단 추출물 농도가 $400 \mu \mathrm{g} / \mathrm{mL}$ 로 처리한 실험군 은 유의한 감소를 나타내었다(Figure $4 \mathrm{C}$ ).

\section{4. 단회 경피 투여 독성 평가}

1) 체중증가, 사료 섭취량 및 음수량 평가

후코이단 추출물을 흰 쥐의 등에 도포한 후 14 일 동안 관찰 한 결과, 모든 동물에서 이상 증상은 보이지 않았으며 체중변화 에 있어 수컷 흰쥐의 경우 약 $153 \mathrm{~g}$ 에서 시작하여 실험 종료 14 일에 $268 \mathrm{~g}$ 으로 꾸준히 증가되었고 암컷 흰쥐의 경우도 약 138 $\mathrm{g}$ 에서 시작하여 실험 종료 14 일에 $242 \mathrm{~g}$ 으로 증가되었다. 식이 섭취량은 모든 동물에서 특이점이 보이지 않았으며, 평균적으로 한 마리 당 $0.16 \mathrm{~g} / \mathrm{g}$ 으로 유지되었다. 물 섭취량 또한 특이점이 보이지 않았으며, 평균적으로 한 마리 당 $0.24 \mathrm{~mL} / \mathrm{g}$ 으로 유지 되었다(Table 2).

\section{2) 장기 무게 변화}

후코이단 추출물 도포 14 일 후 실험 동물을 부검한 결과, 모 든 동물에서 장기의 특이적인 이상 소견이 관찰되지 않았다. 간, 신장, 비장, 폐, 심장을 포함한 장기 무게는 수컷과 암컷 모두 대 조군과 비교하였을 때 차이를 보이지 않았고 결과적으로 후코이 단 추출물이 신체 내부에 영향을 미치지 않는 것으로 판단하였 다.

이상의 결과로 사망 동물은 물론 일반 증상, 체중변화, 부검 및 육안소견 그리고 장기의 무게에 있어서 어떠한 이상 소견도 발견되지 않음으로써 개략의 치사량을 산출할 수 없었으며, 흰 쥐에서 후코이단 추출물의 단회 경피 처치는 $10 \%$ 농도까지 특이 적인 부작용이 없는 것으로 사료된다(Table 3 ).

\section{Conclusion}

본 연구에서는 후코이단 추출물의 화장품 소재로서의 유효성 을 알아보기 위하여 세포독성, 항균, 항염증 효능을 평가하였 다. Skin fibroblast 세포에 후코이단 추출물을 농도별로 처리 한 결과 $1,000 \mu \mathrm{g} / \mathrm{mL}$ 까지 세포독성이 나타나지 않았으며 $S$. aureus 배양 후 후코이단 추출물을 $0.01 \%, 0.1 \%, 1 \%$ 의 농도로 처리한 결과, 농도의존적인 항균활성을 나타내었다. 또한 RAW 264.7 세포에 LPS를 가하여 염증반응을 유발한 후 NO 생성량 및 $\mathrm{IL} 1 \beta, \mathrm{TNF} \alpha, \mathrm{PGE}_{2}$ 와 같은 염증성 사이토카인 생성량을 살 
Table 3. Rat organ weights after single transdermal treatment with fucoidan extract

\begin{tabular}{lcccccccc}
\hline \multirow{2}{*}{ Organ } & \multicolumn{2}{c}{ Vehicle } & \multicolumn{2}{c}{ Fucoidan, $1 \%$} & \multicolumn{2}{c}{ Fucoidan, $5 \%$} & \multicolumn{2}{c}{ Fucoidan, $10 \%$} \\
\cline { 2 - 9 } & $\mathrm{M}$ & $\mathrm{F}$ & $\mathrm{M}$ & $\mathrm{F}$ & $\mathrm{M}$ & $\mathrm{F}$ & $\mathrm{M}$ & $\mathrm{F}$ \\
Liver & $8.58 \pm 0.43$ & $6.42 \pm 0.33$ & $8.48 \pm 0.38$ & $6.35 \pm 0.48$ & $8.51 \pm 0.45$ & $6.44 \pm 0.35$ & $8.53 \pm 0.32$ & $6.38 \pm 0.22$ \\
Kidney & $1.04 \pm 0.10$ & $0.71 \pm 0.10$ & $0.98 \pm 0.08$ & $0.68 \pm 0.10$ & $0.99 \pm 0.11$ & $0.69 \pm 0.08$ & $0.96 \pm 0.08$ & $0.72 \pm 0.12$ \\
Spleen & $0.72 \pm 0.05$ & $0.48 \pm 0.03$ & $0.69 \pm 0.08$ & $0.50 \pm 0.08$ & $0.73 \pm 0.10$ & $0.47 \pm 0.04$ & $0.70 \pm 0.06$ & $0.49 \pm 0.06$ \\
Lung & $1.62 \pm 0.11$ & $1.12 \pm 0.11$ & $1.59 \pm 0.08$ & $1.09 \pm 0.13$ & $1.60 \pm 0.10$ & $1.06 \pm 0.08$ & $1.64 \pm 0.13$ & $1.10 \pm 0.10$ \\
Heart & $1.01 \pm 0.07$ & $0.68 \pm 0.07$ & $0.98 \pm 0.08$ & $0.66 \pm 0.09$ & $1.03 \pm 0.12$ & $0.69 \pm 0.08$ & $0.97 \pm 0.10$ & $0.70 \pm 0.10$ \\
\hline
\end{tabular}

$\mathrm{M}$, male; F, female.

펴본 결과, LPS를 처리하였을 때 $11.7 \pm 1.1 \mu \mathrm{M}$ 로 증가한 $\mathrm{NO}$ 생성량이 후코이단 추출물 $400 \mu \mathrm{g} / \mathrm{mL}$ 농도 처리군에서 $9.5 \pm$ $1.7 \mu \mathrm{M}$ 로 유의하게 감소함을 확인하였다. 그리고 IL1 생성량 은 후코이단으로 처리하였을 때 감소하는 경향을 나타내었고, $\mathrm{TNF} \alpha$ 생성량은 후코이단 추출물 $200,400 \mu \mathrm{g} / \mathrm{mL}$ 농도 처리 군에서 유의한 감소를 나타내었다. $\mathrm{PGE}_{2}$ 생성량 또한 후코이단 추출물 $400 \mu \mathrm{g} / \mathrm{mL}$ 농도 처리군에서 유의하게 감소하여 후코이 단 추출물의 뛰어난 항염증 효능을 확인할 수 있었다. 그리고 후 코이단 추출물을 흰 쥐의 등에 도포한 후 14 일 동안 관찰한 결 과, 모든 동물에서 이상 증상은 보이지 않았으며 체중 및 장기 변 화에서도 영향을 미치지 않음을 확인하였다. 본 실험에서 후코이 단 추출물은 세포독성 및 경피 투여 독성을 나타내지 않았고 $\mathrm{S}$. aureus을 효과적으로 억제하였으며 NO 및 염증성 사이토카인 의 생성량을 감소시켜 항균 및 항염증 화장품으로서의 활용가능 성이 높다고 사료된다. 그러나 염증 차단 기전을 분명히 하기 위 하여 cyclooxygenase 2 (COX2) 발현 억제 효능, iNOS 발현 억 제 효능 등을 살펴 보지 못한 점, P. acnes, M. furfur 등 다양 한 균에 대한 항균실험을 하지 못한 점은 본 연구의 한계점으로 남는다. 따라서 향후 연구에서는 다양한 균을 대상으로 한 후코 이단 추출물의 항균실험과 염증 기전에 따른 실험뿐 아니라 동물 실험을 통한 심도 깊은 연구를 진행하여야 할 것이다.

\section{References}

Bae GC, Bae DY. The anti-inflammatory effects of ethanol extract of Allium Hookeri cultivated in South Korea. The Korea Journal of Herbology, 27: 55-61, 2012.

Cha SH, Lee JS, Kim YS, Kim D, Moon JC, Park K. Properties of fucoidan as raw materials of water-holding cream and cosmetics. Korean Chemical Engineering Research, 48: 27-32, 2010.

Choi JH, Kim DI, Park SH, Kim DW, Kim CM, Koo JG. Effects of sea tangle (Laminaria japonica) extract and fucoidan components on lipid metabolism of stressed mouse. Korean Journal of Fisheries and Aquatic Sciences, 33: 124-128, 2000.

Choi YH, Kim SE, Huh J, Han YH, Lee MJ. Antibacterial and antioxidative activity of roasted coffee and red ginseng mixture extracts. Journal of the Korean Society of Food Science and Nutrition, 41: 320-326, 2012.

Gkogkolou P, Böhm M. Advanced glycation end products: key players in skin aging? Dermato-Endocrinology, 4: 259270, 2012.

Han SM, Lee KG, Yeo JH, Kim WT, Park KK. Antimicrobial property of honeybee (Apis mellifera L.) venom against Propionibacterium acnes and aerobic skin flora. Korean Journal of Pharmacognosy, 40: 173-177, 2009.

Jung HK, Kang BM, Jang JH, Ahn BK, Yeo JH, Jung WS, Cho JH, Kuk YI, Hyun KH, Cho HW. Inhibitory effect of Alopecurus aequalis sobol ethanol extracts on LPSinduced inflammatory response in RAW 264.7 cells. Korean Journal of Medicinal Crop Science, 22: 98-104, 2014.

Kang N, Han EJ, Park SY, Jee Y, Jeon YJ, Ahn CB, Ahn G. Inhibitory effects of Ecklonia cava ethanol extracts against TNF- $\alpha /$ IFN- $\gamma$-induced inflammation in human keratinocytes. Journal of Chitin and Chitosan, 22: 8288, 2017.

Kim HH, Park GH, Park KS, Lee JY, Kim TH, An BJ. The effect of Aster glehni Fr. Schm. extracts on whitening and antiwrinkle. Journal of Life Science, 20: 1034-1040, 2010.

Kim MS, Jeong J, Lee HY, Ju YS, Bae GS, Seo SW, Cho IJ, Park SJ, Song HJ. The anti-inflammatory effect of Achyranthes japonica on lipopolysaccharide-induced inflammatory activity in murine macrophages. The 
Korea Journal of Herbology, 26: 51-57, 2011.

Kim MR, Woo SE, Shin SO, Hong SM, Yang SY. A study on the distribution of Staphylococus aureus in atopic dermatitis. Journal of the Society of Cosmetic Scientists of Korea, 32: 93-97, 2006.

Kim SN, Lee SH, Choi GH, Chang IS, Lee BG. Effects of parsley extract on skin anti-aging and anti-irritation. Journal of the Society of Cosmetic Scientists of Korea, 30: 79-83, 2004.

Kim YS, Lee SJ, Hwang JW, Kim EH, Park PJ, Jeong JH. Anti-inflammatory effects of extracts from Ligustrum ovalifolium $\mathrm{H}$. leaves on RAW264.7 macrophages. Journal of the Korean Society of Food Science and Nutrition, 41: 1205-1210, 2012.

Lee AR, Roh SS, Lee ES, Min YH. Anti-oxidant and antimelanogenic activity of the methanol extract of pine cone. Asian Journal of Beauty and Cosmetology, 14: 301-308, $2016 a$.

Lee SS, Imm JY, Han YS. The improvement effect of lotus leaf extracts on acne skin. Asian Journal of Beauty and Cosmetology, 10: 405-413, 2012.

Lee S, Han HS, An IS, Ahn KJ. Effects of amentoflavone on anti-inflammation and cytoprotection. Asian Journal of Beauty and Cosmetology, 14: 201-211, 2016b.

Nathan CF. Secretory products of macrophages. The Journal of Clinical Investigation, 79: 319-326, 1987.

Oomizu S, Yanase Y, Suzuki H, Kameyoshi Y, Hide M.
Fucoidan prevents $\mathrm{C}$ epsilon germline transcription and NFkappaB p52 translocation for IgE production in B cells. Biochemical and Biophysical Research Communications, 350: 501-507, 2006.

Park JA, Choi MO. Antimicrobial activity and antiinflammation effect to the human skin pathogens by the Rumex crispus L. root extracts. Asian Journal of Beauty and Cosmetology, 9: 9-16, 2011.

Pereira MS, Mulloy B, Mourão PA. Structure and anticoagulant activity of sulfated fucans. comparison between the regular, repetitive, and linear fucans from echinoderms with the more heterogeneous and branched polymers from brown algae. Journal of Biological Chemistry, 274: 7656-7667, 1999.

Rostasy K, Monti L, Yiannoutsos C, Wu J, Bell J, Hedreen J, Navia BA. NFKB activation, TNF- $\alpha$ expression, and apoptosis in the AIDS-Dementia-Complex. Journal of Neurovirology, 6: 537-543, 2000.

Song YS, Balcos MC, Yun HY, Baek KJ, Kwon NS, Kim MK, Kim DS. ERK activation by fucoidan leads to inhibition of melanogenesis in Mel-Ab cells. The Korean Journal of Physiology \& Pharmacology, 19: 29-34, 2015.

Zollner TM, Wichelhaus TA, Hartung A, Von Mallinckrodt C, Wagner TO, Brade V, Kaufmann R. Colonization with superantigen-producing Staphylococcus aureus is associated with increased severity of atopic dermatitis. Clinical \& Experimental Allergy, 30: 994-1000, 2000. 


\section{국문초록}

\section{후코이단 추출물의 항균 및 항산화 효과}

이아름 ${ }^{1}$, 노성수 ${ }^{1}$, 김현경 ${ }^{*}$

${ }^{1}$ 대구한의대학교 한의과대학 본초약리학교실, 대구, 한국

${ }^{2}$ 서원대학교 BIT융합대학 식품공학과, 충청북도 청주시, 한국

목적: 본 연구는 화장품 소재로서 후코이단 추출물의 가능성을 평가하고자 하였다. 방법: Skin fibroblast 세포에 후코이단 추출물 을 여러 농도로 처리하여 세포독성을 알아보았고, 항균 효능을 평가하기 위하여 Staphylococcus aureus (S. aureus)에 후코이단 추출물을 가하여 디스크 주위에 clear zone 직경을 측정하였다. 또한 RAW 264.7 세포에서 항염증 효능을 확인하였고, SpragueDawley $(\mathrm{SD})$ 흰쥐의 피부에 후코이단 추출물을 도포하여 단회 경피 투여 독성 평가를 진행하였다. 결과: 후코이단 추출물을 skin fibroblast 세포에 처리하였을 때 $1,000 \mu \mathrm{g} / \mathrm{mL}$ 까지 세포독성을 나타내지 않았다. 또한 $S$. aureus에 $1 \%$ 후코이단 추출물을 처리하 였을 때 $1.52 \pm 0.34 \mathrm{~cm}$ 의 생육 저해환이 형성되어 충분한 항균 활성을 갖고 있다는 것을 확인하였다. RAW 264.7 세포에 후코이단 추출물을 처리하였을 때 nitric oxide (NO) 생성량은 농도의존적으로 감소하였고, interleukin 1 beta (L1ß), tumor necrosis factor alpha ( $\mathrm{TNF} \alpha)$, prostaglandin $\mathrm{E}_{2}\left(\mathrm{PGE}_{2}\right)$ 와 같은 염증 관련 cytokine은 감소하였다. 동물모델에 후코이단 추출물을 농도별로 도포하 였을 때 14 일 동안 이상증상을 보이지 않았으며 체중, 장기 조직의 무게 변화가 없었다. 결론: 후코이단 추출물은 세포독성을 나타 내지 않으며 항균 및 항염증 효능을 갖고 있어 화장품 소재로서 충분히 활용될 수 있다고 사료된다.

핵심어: 후코이단, 세포독성, 항균, 항염증, 경피 투여 독성

\section{참고문헌}

강나래, 한의정, 박수연, 지영흔, 전유진, 안창범, 안긴내. 피부각질형성세포에서 $\mathrm{TNF}-\alpha / \mathrm{IFN}-\gamma$ 로 유도된 염증반응에 대 한 감태 에탄올 추출물의 억제 효과. 한국키틴키토산학회지, 22: 82-88, 2017.

김미례, 우승은, 신순오, 홍성미, 양시용. 아토피 피부염에서 황색포도상구균 분포에 관한 연구. 대한화장품학회지, 32 : 93-97, 2006.

김민선, 정진수, 이혜윤, 주영승, 배기상, 서상완, 조일주, 박성주, 송호준. LPS로 유도한 대식세포의 염증반응에서 우슬의 항염증 효과. 대한본초학회지, $26: 51-57,2011$.

김수남, 이소희, 최규호, 장이섭, 이병곤. 파슬리추출물의 피부 노화 방지와 자극 완화에 대한 효과. 대한화장품학회지, 30: 79-83, 2004.

김연숙, 이승재, 황진우, 김이화, 박표잠, 정재현. RAW264.7 대식세포에서 왕쥐똥나무잎 추출물의 항염증 효과. 한국식 품영양과학회지, 41: 1205-1210, 2012.

김한혁, 박근혜, 박강수, 이진영, 김태훈, 안봉전. 섬쑥부쟁이(Aster glehni Fr. Schm.) 분획물의 미백 및 주름 개선 효과. 생명과학회지, 20: 1034-1040, 2010.

박주아, 최미옥. 소리쟁이(Rumex crispus L.) 뿌리 추출물의 피부상재균에 대한 항균활성과 항염증 효과. 아시안뷰티화 장품학술지, 9: 9-16. 2011.

배기춘, 배대열. 국내산 삼채 에탄올 추출물의 항염증 효과. 대한본초학회지, 27: 55-61, 2012.

이선숙, 임지영, 한영숙. 연잎 추출물의 여드름 피부 개선 효과. 아시안뷰티화장품학술지, 10: 405-413, 2012.

이송정, 한효선, 안인숙, 안규중. Amentoflavone의 항염증 및 세포 보호 효과. 아시안뷰티화장품학술지, 14: 201-211, 2016.

이아름, 노성수, 이은숙, 민유홍. 솔방울 메탄올 추출물의 항산화 및 멜라닌 생성 억제 효과. 아시안뷰티화장품학술지, 14 : 
301-308, 2016.

정호경, 강병만, 장지훈, 안병관, 여준환, 정원석, 조정희, 국용인, 현규환, 조현우. LPS로 유도한 RAW 264.7 세포의 염 증반응에서 뚝새풀 에탄올 추출물의 억제 효과. 한국약용작물학회지, 22: 98-104, 2014.

차성한, 이정식, 김영숙, 김동욱, 문재천, 박권필, 후코이단의 보습제 및 화장품재료로서 특성. 화학공학, 48: 27-32, 2010.

최유현, 김상은, 허진, 한영환, 이문조. 로스팅 커피와 홍삼 혼합추출물의 항균 및 항산화 효과. 한국식품영양과학회지, 41: 320-326, 2012.

최진호, 김대익, 박수현, 김동우, 김창목, 구재근. 스트레스 부하 마우스의 지질대사에 미치는 다시마(Laminaria japonica)와 후코이단 성분의 영향. 한국수산과학회지, 33: 124-128, 2000.

한상미, 이광길, 여주홍, 김원태, 박관규. 국내산 봉독의 여드름 유발균 및 피부 상재균 증식 억제 효과. 생약학회지, $40:$ 173-177, 2009. 


\section{中文摘要}

\section{褐藻糖胶（Fucoidan）提取物的抗菌活性和抗炎作用}

李아름 ${ }^{1}$, 卢盛洙 ${ }^{1}$, 金賢京 $^{2^{*}}$

${ }^{1}$ 大邱韩医大学本草药理学科, 大邱, 韩国

${ }^{2}$ 西原大学BIT融合大学食品工学科, 忠淸北道清州市, 韩国

目的: 本研究旨在评估褐藻糖胶提取物作为化妆品原料的可行性。方法: 在皮肤成纤维细胞中, 用不同浓度的褐藻 糖胶提取物处理, 并确认其细胞毒性。为评估抗菌作用, 用褐藻糖胶提取物处理金黄色葡萄球菌（Staphylococcus aureus，S. aureus）并测量其抑制区域。另外，在RAW 264.7细胞中，确认了抗炎作用；将褐藻糖胶提取物施 用于Sprague-Dawley（SD）大鼠的背部皮肤, 评估其单剂量毒性。结果: 褐藻糖胶提取物在皮肤成纤维细胞 中, 浓度高达 $1,000 \mu \mathrm{g} / \mathrm{mL}$ 时，不显示细胞毒性。此外，当用 $1 \%$ 褐藻糖胶提取物处理金黄色葡萄球菌时，形成 了1.52 $0.34 \mathrm{~cm}$ 的清晰区域, 证实了足够的抗菌活性。当RAW 264.7 细胞用褐藻糖胶提取物处理时, 一氧化氮

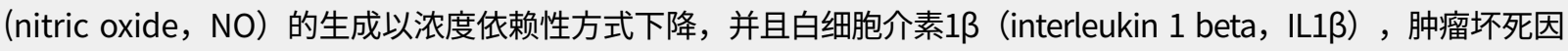
子a (tumor necrosis factor alpha, TNFa) 和前列腺素 $E_{2}$ (prostaglandin $E_{2}, P G E_{2}$ ) 等炎症相关细胞因子的含 量也下降。当褐藻糖胶以不同浓度施用于大鼠时, 症状在14天内没有改变, 并且体重或器官重量都没有变化。 结论：褐藻糖胶提取物不仅不具有细胞毒性而且还具有抗微生物和抗炎作用。因此，它适合用作化妆品原料。

关键词: 褐藻糖胶, 细胞毒性, 抗菌, 抗炎症, 经皮投药毒性 